\title{
KONTRIBUSI EKONOMI ISLAM DALAM \\ PEMBANGUNAN EKONOMI NASIONAL
}

\author{
TIRA NUR FITRIA \\ STIE - AAS Surakarta \\ Email: tiranurfitria@yahoo.co.id
}

\begin{abstract}
ABSTRAK
Islam sebagai sistem kehidupan yang universal, integral, dan komprehensif telah menetapkan tatanan yang utuh untuk kehidupan manusia. Sebagai way of life, Islam menata segala hal yang berkaitan dengan kehidupan, dari hal yang paling sederhana hingga urusan yang paling rumit sekalipun. Baik dalam aspek politik, ekonomi, pendidikan, seni, sosial, budaya, dsb. Islam merupakan agama yang sempurna, yang mengatur hal yang berkaitan dengan ekonomi. Apabila perekonomian suatu negara (ekonomi nasional) menerapkan dasar Al-Quran dan Hadist sebagai dasar penerapannya, tentunya suatu perekonomian nasional akan berjalan dengan baik dan terarah sesuai aturan. Namun kenyataanya memang belum semua negara muslim di dunia menerapkan dasar tersebut. Selanjutnya, di dalam artikel ini dijelaskan tentang bagaimana Ekonomi Islam berkontribusi dalam pembangunan ekonomi nasional, khususnya Indonesia sebagai negara dengan basis muslim terbesar se-Asia.
\end{abstract}

Kata kunci: Ekonomi Islam, Pembangunan Ekonomi Nasional

\section{PENDAHULUAN}

Ekonomi Islam dalam tiga dasawarsa ini mengalami kemajuan yang cukup pesat, baik dalam kajian akademis di perguruan tinggi maupun dalam praktek operasional. Dalam bentuk pengajaran, ekonomi Islam telah dikembangkan di beberapa universitas baik di negara-negara muslim, maupun di negaranegara barat, seperti USA, Inggris, Australia, dan lainnya.

Di Indonesia, perkembangan pembelajaran dan pelaksanaan ekonomi islam juga telah mengalami kemajuan yang pesat. Pembelajaran tentang ekonomi islam telah diajarkan di beberapa perguruan tinggi negeri maupun swasta. Perkembangan ekonomi islam telah mulai mendapatkan momentum sejak didirikannya Bank Muamalat pada tahun 1992. Berbagai Undang-Undangnya yang mendukung tentang sistem ekonomi tersebut pun mulai dibuat, seperti UU No. 7 Tahun 1992 tentang Perbankan sebagaimana yang telah diubah dalam Undang-undang Nomor 10 Tahun 1998 dan Undang-undang Nomor 23 Tahun 1999 tentang Bank Indonesia.

\section{PEMBAHASAN}

\section{Pengertian Ekonomi Islam dan}

Pembangunan Ekonomi

Pengertian pembangunan ekonomi dalam Islam, berdasarkan pemahaman terhadap syari'ah, bersumber dari al-qur'ân dan alhadîs, dengan penekanan bahwa keberhasilan 
pembangunan harus disertai pengetahuan tentang konsep-konsep pembangunan klasik dan modern, serta pengalaman negara-negara yang telah berhasil dalam melakukan usaha pembangunan.

Pembangunan dalam pemikiran Islam bermula dari kata 'imârah (عَمَارَ) atau ta'mîr (تَعْمِيْرِ), sebagaimana isyarat dalam Q.S. Hud: 61.'...Dia (Allah) telah menciptakan kamu dari bumi (tanah) dan meminta kamu untuk memakmurkannya...' dihubungkan dengan penciptaan manusia sebagai khalifah di bumi, Q.S. al-Baqarah: 30. 'Dan ketika Tuhanmu berfirman kepada para malaikat: Sesungguhnya Aku menjadikan khalifah di muka bumi...' yakni manusia yang ditugaskan untuk melakukan pembangunan, sehingga tercipta kemakmuran.

Kalimat ista'mara (اسنتَعْمَرَ) yang berasal dari kata 'amara' (عَ) bermakna: permintaan atau perintah daru Allah yang bersifat mutlak agar bangsa manusia menciptakan kemakmuran di muka bumi melalui usaha pembangunan.

Sebagaimana dijelaskan Al-Qurţubî dalam kitab tafsirnya, bahwa ayat tersebut mengandung arti 'perintah' bersifat mutlak dan hukumnya adalah wajib 'agar manusia memakmurkan kehidupan dengan melakukan pembangunan.

Pembangunan (development) adalah proses perubahan yang mencakup seluruh system sosial, seperti politik, ekonomi, infrastruktur, pertahanan, pendidikan dan teknologi, kelembagaan, dan budaya (Alexander 1994). Portes (1976) mendefenisiskan pembangunan sebagai transformasi ekonomi, sosial dan budaya.
Pembangunan adalah proses perubahan yang direncanakan untuk memperbaiki berbagai aspek kehidupan masyarakat.

Menurut Nurcholis Madjid (pembangunan merupakan pemenuhan fungsi kekhalifahan manusia di muka bumi yang akan dipertanggungjawabkannya nanti di hadapan Allah. Penjabaran pemenuhan fungsi kekhalifahan ini sangat penting artinya, agar manusia mengerti benar caranya berperan. Penjabaran ini memerlukan reinterpretasi terhadap berbagai konsep pembangunan. Dawam Rahardjo (1983) pembangunan merupakan pemenuhan fungsi kekhalifahan, dengan merealisasikan sibghah Allah dalam mewujudkan ummatan wasathan.

Sedangkan istilah pembangunan ekonomi (economic development) biasanya dikaitkan dengan perkembangan ekonomi di negara-negara berkembang. Sebagian ahli ekonomi mengartikan istilah ini sebagai berikut, "economic development is growth plus change" (Pembangunan ekonomi adalah pertumbuhan ekonomi yang diikuti oleh perubahan-perubahan dalam struktur dan corak kegiatan ekonomi).

Dengan kata lain, dalam mengartikan istilah pembangunan ekonomi, ekonom bukan saja tertarik kepada masalah perkembangan pendapatan nasional riil, tetapi juga kepada modernisasi kegiatan ekonomi, misalnya kepada usaha perombakan sektor pertanian yang tradisional, mempercepat pertumbuhan ekonomi dan pemerataan pendapatan.

Dalam kajian ekonomi, kedua istilah di atas terkadang digunakan dalam konteks yang hampir sama. Banyak orang mencampuradukkan penggunaan kedua 
istilah tersebut. Pencampur adukan istilah ini walaupun tidak dapat dibenarkan, pada dasarnya tidak terlalu mempengaruhi kajian ekonomi, karena inti pembahasan pada akhirnya akan berhubungan erat dengan perkembangan perekonomian suatu negara.

Dalam berbagai literatur tentang ekonomi Islam, kedua istilah ini juga ditemukan. Ekonomi Islam pada dasarnya memandang bahwa pertumbuhan ekonomi adalah bagian dari pembangunan ekonomi. Pertumbuhan ekonomi didefenisikan dengan a suistained growth of a right kind of output which can contribute to human welfare. (Pertumbuhan terus-menerus dari faktor produksi secara benar yang mampu memberikan konstribusi bagi kesejahteraan manusia).

Berdasarkan pengertian ini, maka pertumbuhan ekonomi menurut Islam merupakan hal yang sarat nilai. Suatu peningkatan yang dialami oleh faktor produksi tidak dianggap sebagai pertumbuhan ekonomi jika produksi tersebut misalnya memasukkan barang-barang yang terbukti memberikan efek buruk dan membahayakan manusia.

Sedangkan istilah pembangunan ekonomi yang dimaksudkan dalam Islam adalah the process of allaviating poverty and provision of ease, comfort and decency in life (Proses untuk mengurangi kemiskinan serta menciptakan ketentraman, kenyamanan dan tata susila dalam kehidupan)

Dalam pengertian ini, maka pembangunan ekonomi menurut Islam bersifat multi dimensi yang mencakup aspek kuantitatif dan kualitatif. Tujuannya bukan semata-mata kesejahteraan material di dunia, tetapi juga kesejahteraan akhirat. Keduanya menurut Islam menyatu secara integral.

\section{Sejarah Berdirinya Ekonomi Islam}

Sebenarnya aksi maupun pemikiran tentang ekonomi berdasarkan islam memiliki sejarah yang amat panjang. Pada sekitar tahun 1911 telah berdiri organisasi Syarikat Dagang Islam (SDI) yang beranggotakan tokoh-tokoh atau intelektual muslim saat itu, serta ekonomi islam ini sesuai dengan pedoman seluruh umat islam di dunia yaitu di dalam Al-Qur'an yang mengatakan bahwa jika kamu akan bermuamalah, hendaklah kamu menuliskannya dengan benar, dan hendaklah orang yang berutang itu mengimlakannya (apa yang akan dituliskan itu), dan janganlah orang itu mengurangi sedikit pun dari utangnya. Jika orang yang mengutang itu lemah akalnya atau lemah keadaanya atau tidak mampu mengimlakannya, maka hendaklah walinya yang mengimlakannya dengan jujur. Selain itu juga harus didatangkan dua orang saksi dari orang lelaki. Jika tidak ada maka boleh dengan seorang lelaki dan dua orang perempuan dari saksisaksi yang kamu kehendaki, dan jangalah saksi itu enggan memberikan memberi keterangan apabila mereka dipanggil, dan janganlah engkau jemu menulis utang itu baik kecil maupun besar sampai batas waktu pembayaranya. Kecuali jika muamalah itu perdagangan tunai kamu, maka tak ada dosa bagi kamu jika kamu tidak menuliskanya. Dan persaksikanlah apabila kau berjual beli, dan janganlah penulis dan saksi saling menyulitkan (Q, S Al-Baqarah: 282). 
Perkembangan ekonomi islam yang semakin marak ini merupakan cerminan dan kerinduan umat islam di Indonesia ini khususnya seorang pedagang, berinvestasi, bahkan berbisnis yang secara islami dan diridhoi oleh Allah SWT. Dukungan serta komitmen dari Bank Indonesia dalam keikutsertaanya dalam perkembangan ekonomi islam dalam negeripun merupakan jawaban atas gairah dan kerinduan dan telah menjadi awalan bergeraknya pemikiran dan praktek ekonomi islam di dalam negeri, juga sebagai pembaharuan ekonomi dalam negeri yang masih penuh kerusakan ini, serta awal kebangkitan ekonomi islam di Indonesia maupun di seluruh dunia, misalnya di Indonesia berdiri Bank Muamalat tahun 1992.

Pada awal tahun 1997, terjadi krisis ekonomi di Indonesia yang berdampak besar terhadap goncangan lembaga perbankan yang berakhir likuidasi pada sejumlah bank, Bank Islam atau Bank Syariah malah bertambah semakin pesat. Pada tahun 1998, sistem perbankan islam dan gerakan ekonomi islam di Indonesia mengalami kemajuan yang sangat pesat.

\section{Perkembangan Ekonomi Islam Di Indonesia}

Dikutip dalam sebuah artikel bahwa, "Di Indonesia, praktek ekonomi Islam, khususnya perbankan syariah sudah ada sejak 1992. Diawali dengan berdirinya Bank Muamalat Indonesia (BMI) dan Bank-bank Perkreditan Rakyat Syariah (BPRS). Namun, pada decade hingga tahun 1998, perkembangan bank syariah boleh dibilang agak lambat. Pasalnya, sebelum terbitnya $U U$
No. 10 Tahun 1998 tentang Perbankan, tidak ada perangkat hukum yang mendukung sistem operasional bank syariah kecuali UU No. 7 Tahun 1992 dan PP No. 72 Tahun 1992.

Berdasarkan UU No. 7 Tahun 1992 itu bank syariah dipahami sebagai bank bagi hasil. Selebihnya bank syariah harus tunduk kepada peraturan perbankan umum yang berbasis konvensional. Karenanya manajemen bank-bank syariah cenderung mengadopsi produk-produk perbankan konvensional yang "disyariatkan". Dengan variasi produk yang terbatas. Akibatnya tidak semua keperluan masyarakat terakomodasi dan produk yang ada tidak kompetitif terhadap semua produk bank konvensional."

Perkembangan sistem ekonomi syariah di indonesia sendiri belum sebegitu pesat seperti di negara-negara lain, Secara sederhana, perkembangan itu dikelompokkan menjadi perkembangan industri keuangan syariah dan perkembangan ekonomi syariah non keuangan. Industri keuangan syariah relatif dapat dilihat dan diukur perkembangannya melalui data-data keuangan yang ada, sedangkan yang non keuangan perlu penelitian yang lebih dalam untuk mengetahuinya.

Di sektor perbankan, hingga saat ini sudah ada tiga Bank Umum Syariah (BUS), 21 unit usaha syariah bank konvensional, 528 kantor cabang (termasuk Kantor Cabang Pembantu (KCP), Unit Pelayanan Syariah (UPS), dan Kantor Kas (KK)), dan 105 Bank Pengkreditan Rakyat Syariah (BPRS). Aset perbankan syariah per Maret 2007 lebih dari Rp. 28 triliun dengan jumlah Dana Pihak Ketiga (DPK) hampir mencapai 22 Triliun. 
Meskipun asset perbankan syariah baru mencapai 1,63 persen dan dana pihak ketiga yang dihimpun baru mencapai 1,64\% dari total asset perbankan nasional (per Februari 2007), namun pertumbuhannya cukup pesat dan menjanjikan. Diproyeksikan, pada tahun 2008, share industri perbankan syariah diharapkan mencapai 5 persen dari total industri perbankan nasional.

Di sektor pasar modal, produk keuangan syariah seperti reksa dana dan obligasi syariah juga terus meningkat. Sekarang ini terdapat 20 reksa dana syariah dengan jumlah dana kelola 638,8 miliar rupiah. Jumlah obligasi syariah sekarang ini mencapai 17 buah dengan nilai emisi mencapai 2,209 triliun rupiah.

Di sektor saham, pada tanggal 3 Juli 2000 BEJ meluncurkan Jakarta Islamic Index (JII). JII yang merupakan indeks harga saham yang berbasis syariah terdiri dari 30 saham emiten yang dianggap telah memenuhi prinsipprinsip syariah. Data pada akhir Juni 2005 tercatat nilai kapitalisasi pasar sebesar Rp325,90 triliun atau $43 \%$ dari total nilai kapitalisasi pasar di BEJ. Sementara itu, volume perdagangan saham JII sebesar 348,9 juta lembar saham atau 39\% dari total volume perdagangan saham dan nilai perdagangan saham JII sebesar Rp322,3 miliar atau 42\% dari total nilai perdagangan saham. Peranan pemerintah yang sangat ditunggu-tunggu oleh pelaku keuangan syariah di Indonesia adalah penerbitan Undang-undang Perbankan Syariah dan Undang-undang Surat Berharga Negara Syariah (SBSN).

Di sektor asuransi, hingga Agustus 2006 ini sudah lebih 30 perusahaan yang menawarkan produk asuransi dan reasuransi syariah. Namun, market share asuransi syariah belum baru sekitar $1 \%$ dari pasar asuransi nasional. Di bidang multifinance pun semakin berkembang dengan meningkatnya minat beberapa perusahaan multifinance dengan pembiayaan secara syariah. Angka-angka ini diharapkan semakin meningkat seiiring dengan meningkatnya permintaan dan tingkat imbalan (rate of return) dari masing-masing produk keuangan syariah.

Di sektor mikro, perkembangannya cukup menggembirakan. Lembaga keuangan mikro syariah seperti Baitul Mal wa Tamwil (BMT) terus bertambah, demikian juga dengan aset dan pembiayaan yang disalurkan. Sekarang sedang dikembangkan produk-produk keuangan mikro lain semisal micro-insurance dan mungkin micro-mutual-fund (reksa dana mikro).

Industri keuangan syariah adalah salah satu bagian dari bangunan ekonomi syariah. Sama halnya dengan ekonomi konvensional, bangunan ekonomi syariah juga mengenal aspek makro maupun mikro ekonomi. Namun, yang lebih penting dari itu adalah bagaimana masyarakat dapat berperilaku ekonomi secara syariah seperti dalam hal perilaku konsumsi, giving behavior (kedermawanan), dan sebagainya. Perilaku bisnis dari para pengusaha Muslim pun termasuk dalam sasaran gerakan ekonomi syariah di Indonesia.

Walau terlihat agak lambat, namun sisi nonkeuangan dalam kegiatan ekonomi ini juga semakin berkembang. Hal ini ditandai semakin meningkatnya kesadaran masyarakat 
terhadap perilaku konsumsi yang Islami, tingkat kedermawanan yang semakin meningkat ditandai oleh meningkatnya dana zakat, infaq, waqaf, dan sedekah yang berhasil dihimpun oleh badan dan lembaga pengelola dana tersebut.

\section{Kendala Perbankan Syariah}

Banyak tantangan dan permasalahan yang dihadapi dalam perkembangan Bank Syari'ah, berkaitan dengan penerapan suatu sistem perbankan yang baru yang mempunyai sejumlah perbedaan prinsip dari sistem keuntungan yang dominan dan telah berkembang pesat di Indonesia. Permasalahan ini dapat berupa permasalahan yang bersifat operasional perbankan maupun aspek dari lingkungan makro. Beberapa kendala yang dihadapi dalam pengembangan Bank Syari'ah antaranya:

\section{Permodalan}

Permasalahan pokok yang senantiasa dihadapi dalam pendirian suatu usaha adalah permodalan. Setiap ide ataupun rencana untuk mendirikan Bank Syari'ah sering tidak dapat terwujud sebagai akibat tidak adanya modal yang cukup untuk pendirian Bank Syari'ah tersebut, walaupun dari sisi niat ataupun "ghiroh" para pendiri relatif sangat kuat. Kesulitan dalam pemenuhan permodalan ini antara lain disebabkan karena :

a. Belum adanya keyakinan yang kuat pada pihak pemilik dana akan prospek dan masa depan keberhasilan Bank Syari'ah, sehingga ditakutkan dana yang ditempatkan akan hilang. b. Masih kuatnya perhitungan bisnis keduniawian pada pemilik dana sehingga ada rasa keberatan jika harus menempatkan sebagian dananya pada Bank Syari'ah sebagai modal.

c. Ketentuan terbaru tentang Permodalan yang ditetapkan oleh Bank Indonesia relatif cukup tinggi.

\section{Peraturan Perbankan}

Peraturan Perbankan yang berlaku belum sepenuhnya mengakomodir operasional Bank Syari'ah mengingat adanya sejumlah perbedaan dalam pelaksanaan operasional Bank Syari'ah dengan Bank Konvensional. Ketentuan-ketentuan perbankan yang ada kiranya masih perlu disesuaikan agar memenuhi ketentuan syari'ah agar Bank Syari'ah dapat beroperasi secara relatif dan efisien. Ketentuan-ketentuan tersebut antara lain adalah hal-hal yang mengatur mengenai :

a. Instrument yang diperlukan untuk mengatasi masalah likuiditas.

b. Instrument moneter yang sesuai dengan prinsip syari'ah untuk keperluan pelaksanaan tugas Bank Sentral.

c. Standar akuntansi, audit dan pelaporan.

d. Ketentuan-ketentuan yang mengatur mengenai prinsip kehati-hatian, dll.

e. Ketentuan-ketentuan di atas sangat diperlukan agar Bank Syari'ah dapat menjadi elemen dari sistem moneter yang dapat menjalankan fungsinya secara baik dan mampu berkembang dan bersaing dengan Bank Konvensional. 
Sumber Daya Manusia

Kendala dibidang SDM dalam pengembangan Perbankan Syari'ah disesabkan karena sistem perbankan syari'ah masih belum lama dikenal di Indonesia. Disamping itu lembaga akademik dan pelatihan ini masih terbatas, sehingga tenaga terdidik dan berpengalaman dibidang perbankan syari'ah baik dari sisi bank pelaksana maupun bank sentral (pengawas dan peneliti bank).

\section{Pengembangan SDM dibidang} Perbankan Syari'ah sangat diperlukan karena keberhasilan pengembangan bank syari'ah pada level mikro sangat ditentukan oleh kualitas manajemen dan tingkat pengetahuan serta ketrampilan pengelola bank. SDM dalam perbankan syari'ah memerlukan persyaratan pengetahuan yang luas dibidang perbankan, memahami implementasi prinsipprinsip syari'ah dalam praktek perbankan serta mempunyai komitmen kuat untuk menerapkannya secara konsisten.

\section{Pemahaman Ummat}

Pemahaman sebagian besar masyarakat mengenai sistem dan prinsip Perbankan Syari'ah belum tepat, bahkan diantara ulama dan cendekiawan muslim sendiri masih belum ada kata sepakat yang mendukung keberadaan Bank Syari'ah, terbukti dari hasil pretest terhadap 37 Dosen Fakultas Syari'ah dalam acara Orientasi Perbankan yang telah dilakukan oleh Asbisindo Wilayah Jatim beberapa waktu yang lalu memberikan jawaban yang tidak konsekwen dan cenderung ragu-ragu. Dan masih adanya masyarakat yang mengaku paham akan
Syari'ah Islam tetapi tidak mau menjalankannya seperti yang dialami oleh PT. BPR Syari'ah Baktimakmur Indah Sidoarjo dalam memberikan pembiayaan mudharabah dengan salah satu mitranya yang dikenal sebagai ulama yang mana sang ulama mau berbagi kerugian namun setelah untung tidak bersedia membagi keuntungannya dengan pihak Bank, yang tentunya bertentangan dengan akad yang telah disepakati di awal. Atau seorang ulama yang datang ke Bank dan menanyakan besarnya bunga atas simpanannya.

Hal-hal seperti di atas merupakan kejadian nyata yang selalu dan kerap kali dialami dalam operasional bank Syari'ah sehari-harinya, bahkan mungkin lebih parah dari contoh-contoh di atas. Dari kalangan ulama sendiri sampai saat ini belum ada ketegasan pendapat terhadap keberadaan Bank Syari'ah, kekurangtegasan tersebut antara lain disebabkan karena :

a. Kurang komprehensifnya informasi yang sampai kepada para ulama dan cendekiawan tentang bahaya dan dampak destruktif sistem bunga terutama pada saat krisis moneter dan ekonomi dilanda kelesuan.

b. Belum berkembangluasnya lembaga keuangan syari'ah sehingga ulama dalam posisi sulit untuk melarang transaksi keuangan konvensional yang selama ini berjalan dan berkembang luas.

c. Belum dipahaminya operasional Bank Syari'ah secara mendalam dan keseluruhan.

d. Adanya kemalasan intelektual yang cenderung pragmatis sehingga muncul 
anggapan bahwa sistem bunga yang berlaku saat ini sudah berjalan atau tidak bertentangan dengan ketentuan agama.

Minimnya pemahaman masyarakat akan Sistem Perbankan Syari'ah antara lain disebabkan karena :

a. Sistem dan prinsip operasional Perbankan Syari'ah relatif baru dikenal dibanding dengan sistem bunga.

b. Pengembangan Perbankan Syari'ah baru dalam tahap awal jika dibandingkan dengan Bank Konvensional yang telah ratusan tahun bahkan sudah mendarah daging dalam masyarakat.

c. Keengganan bagi pengguna jasa perbankan konvensional untuk berpindah ke Bank Syari'ah disebabkan hilangnya kesempatan untuk mendapatkan penghasilan tetap dari bunga.

\section{Sosialisasi}

Sosialisasi yang telah dilakukan dalam rangka memberikan informasi yang lengkap dan besar mengenai kegiatan usaha perbankan syari'ah kepada masyarakat luas belum dilakukan secara maksimal. Tanggungjawab kegiatan sosialisasi ini tidak hanya dipundak para bankir syari'ah sebagai pelaksana operasional bank sehari-hari, tetapi tanggungjawab semua pihak yang mengaku Islam secara baik secara perorangan, kelompok maupun instansi yang meliputi unsur alim ulama, penguasa negara/pemerintahan, cendekiawan, dll. Yang memiliki kemampuan dan akses yang besar dalam penyebarluasan informasi terhadap masyarakat luas. Sosialisasi yang dilakukan tidak hanya kepada masyarakat awam tetapi juga kepada ulama, pondok pesantren, ormasormas, instansi, institusi, pengusaha, dll. Yang selama ini belum tahu ataupun belum memahami secara detail apa dan bagaimana keberadaan dan operasional Bank Syari'ah walaupun dari sisi Fiqih dan Syari'ah mereka tahu benar.

\section{Piranti Moneter}

Piranti Moneter yang pada saat ini masih mengacu pada sistem bunga sehingga belum bisa memenuhi dan mendukung kebijakan moneter dan kegiatan usaha bank syari'ah, seperti kelebihan/kekurangan dana yang terjadi pada Bank Syari'ah ataupun pasar uang antar bank syari'ah dengan tetap memperhatikan prinsip syari'ah. Bank Indonesia selaku penentu kebijakan perbankan mencoba untuk menyiapkan piranti moneter yang sesuai dengan prinsip syari'ah seperti halnya SBI dan SBPU yang berlandaskan syari'ah Islam.

\section{Jaringan Kantor}

Pengembangan jaringan kantor Bank Syari'ah diperlukan dalam rangka perluasan jangkauan pelayanan kepada masyarakat. Disamping itu kurangnya jumlah Bank Syari'ah yanga ada juga menghambat perkembangan kerjasama antar Bank Syari'ah. Jumlah jaringan kantor bank yang luas juga akan meningkatkan efisiensi usaha serta meningkatkan kompetisi ke arah peningkatan kulaitas pelayanan dan mendorong inovasi produk dan jasa perbankan syari'ah. 
Pengembangan jaringan Perbankan Syari'ah dapat dilakukan dengan beberapa cara antara lain:

a. Peningkatan kualitas Bank Umum Syari'ah dan BPR Syari'ah yang telah beroperasi.

b. Perubahan kegiatan usaha Bank Konvensional yang memiliki kondisi usaha yang baik dan berminat untuk melakukan kegiatan usaha bank berdasarkan prinsip syari'ah.

c. Pembukaan kantor cabang syari'ah (full branch) bagi bank konvensional yang memiliki kondisi usaha yang baik dan berminat untuk melakukan kegiatan usaha berdasarkan prinsip syari'ah.

d. Pembukaan kantor cabang syari'ah dapat dilakukan dengan 3 cara antara lain :

e. Pembukaan kantor cabang dengan mendirikan kamtor, perlengkapan dan SDM yang baru.

f. Mengubah kantor cabang yang ada menjadi kantor cabang syari'ah.

g. Meningkatkan status kantor cabang pembantu menjadi kantor cabang syari'ah.

\section{Pelayanan}

Dunia perbankan senantiasa tidak terlepas pada masalah persaingan, baik dari sisi rate/margin yang diberikan maupun pelayanan. Dari hasil survei lapangan membuktikan bahwa kualitas pelayanan merupakan peringkat pertama kenapa masyarakat memilih bergabung dengan suatu bank.

Dewasa ini semua Bank Konvensional berlomba-lomba untuk senantiasa memperhatikan dan meningkatkan pelayanan kepada nasabah, tidak telepas dalam hal ini Bank Syari'ah yang dalam operasionalnya juga memberikan jasa tentunya unsur pelayanan yang baik dan islami hahrus diperhatikan dan senantiasa ditingkatkan. Tentunya hal ini harus didukung oleh adanya SDM yang cukup handal dibidangnya. Kesan kotor, miskin dan tampil ala kadarnya yang selama ini melekat pada "Islam" harus dihilangkan.

\section{Penerapan Kembali Ekonomi Syariah di Indonesia}

Indonesia merupakan salah satu negara Islam terbesar di dunia. Dengan kata lain umat muslim di Indonesia sangat membutuhkan segala sesuatu yang halal, termasuk hukum syariah dalam ekonomi Islam.

Ketua DPP Ikatan Ahli Ekonomi Islam Indonesia (IAEI), Agustianto menjelaskan bahwa sejarah pergerakan ekonomi Islam di Indonesia telah berlangsung sejak tahun 1911, yaitu sejak berdirinya organisasi Syarikat Dagang Islam yang dibidangi oleh para entrepreneur dan para tokoh Muslim saat itu. "Artinya ekonomi Islam sudah di jalankan sejak jaman itu," kata dia.

Melihat perkembangan ekonomi syariah saat ini, dapat dikatakan adalah cerminan dan kerinduan umat Islam Indonesia untuk kembali menghidupkan semangat para entrepreneur muslim masa silam dalam dunia bisnis dan perdagangan, sebagaimana juga menjadi ajaran Nabi Muhammad SAW dan sunah yang diteladankannya kepada umatnya. 
"Dalam masa yang panjang peran umat Islam dalam dunia bisnis dan perdagangan di Indonesia cenderung termarginalkan. Perkembangan ekonomi Islam di Indonesia mulai mendapatkan momentumnya untuk tumbuh kembali, baru beberapa tahun belakangan ini," kata dia.

Ekonomi syariah tumbuh kembali semenjak didirikannya Bank Muamalat Indonesia pada tahun 1992, setelah mendapat legitimasi legal formal dengan berlakunya Undang-Undang Nomor 7 Tahun 1992 tentang Perbankan. Dua tahun setelah BMI berdiri, lahir pula Asuransi Syariah Takaful di tahun 1994. Berbarengan dengan itu, tumbuh pula 78 BPR Syariah. Pada tahun 1996 berkembang pula lembaga keuangan mikro syariah BMT.

Namun sayangnya, Lembaga Perguruan Tinggi yang mengajarkan ekonomi syariah masih sangat langka. Tercatat, IAIN-SU Medan menjadi Perguruan Tinggi pertama di Indonesia yang membuka Program Studi D3 Manajemen Bank Syari'ah sebagai hasil kerja Forum Kajian Ekonomi dan Bank Islam (FKEBI) yang lahir tahun 1990 sebagai realisasi kerja sama dengan IIUM Malaysia.

Agustianto menjelaskan, perkembangan ekonomi syariah dalam bentuk lembaga perbankan dan keuangan syariah memang menunjukkan perkembangannya yang sangat pesat. Orang yang akan melakukan ekonomi syariah sudah dapat dengan mudah didukung oleh lembaga- lembaga perekonomian Islam seperti Perbankan Syariah, Asuransi Syariah, Pasar Modal Syariah, Reksadana Syariah, Obligasi Syariah, Leasing Syariah, Bank Pembiayaan Rakyat Syariah, Baitul Mal wat
Tamwil, Koperasi Syariah, Pegadaian Syariah, Dana Pensiun Syariah, lembaga keuangan publik Islam seperti Lembaga Pengelola Zakat dan Lembaga Pengelola Wakaf serta berbagai bentuk bisnis syariah lainnya.

Namun sayangnya, meskipun perkembangan lembaga perbankan dan keuangan syariah demikian cepat, namun dari sisi hukum atau peraturan perundangundangan yang mengaturnya masih jauh tertinggal, termasuk hukum-hukum yang berkaitan dengan penyelesaian sengketa bisnis (hukum dagang) syariah.

"Padahal secara yuridis, penerapan hukum ekonomi syariah di Indonesia memiliki dasar hukum yang sangat kuat," katanya. Dengan perkembangan ekonomi global dan semakin meningkatnya minat masyarakat terhadap ekonomi dan perbankan Islam, ekonomi Islam menghadapi berbagai permasalahan dan tantangan-tantangan yang besar.

Ada lima problem dan tantangan yang dihadapi ekonomi Islam saat ini, pertama, masih minimnya pakar ekonomi Islam berkualitas yang menguasai ilmu-ilmu ekonomi modern dan ilmu-ilmu syariah secara integratif. Kedua, ujian atas kredibilitas sistem ekonomi dan keuangannya, ketiga, perangkat peraturan, hukum dan kebijakan, baik dalam skala nasional maupun internasional masih belum memadai.

Keempat, masih terbatasnya perguruan Tinggi yang mengajarkan ekonomi Islam dan masih minimnya lembaga tranining dan consulting dalam bidang ini, sehingga SDI di bidang ekonomi dan keuangan syariah masih 
terbatas dan belum memiliki pengetahuan ekonomi syariah yang memadai. Kelima, peran pemerintah baik eksekutif maupun legislatif, masih rendah terhadap pengembangan ekonomi syariah, karena kurangnya pemahaman dan pengetahuan mereka tentang ilmu ekonomi Islam.

"Dalam menerapkan kembali ekonomi syariah di Indonesia maka yang sangat perlu diperhatikan adalah peranan pemerintah yang tidak hanya memperhatikan segi regulasi dan legal formal saja, tetapi juga keberpihakan yang riil kepada lembaga perbankan dan keuangan syari'ah dalam kebijakan ekonomi dan pembangunan," katanya.

Misalnya, seperti suntikan modal, pembiayaan proyek pembangunan, tabungan dan setoran haji, pendirian Asuransi dan Bank BUMN Syariah. Selain itu, ekonomi syariah, tidak hanya bisa bergantung pada lembaga keuangan syariah itu sendiri, tidak juga hanya bergantung pada peran pakar seperti IAEI (Ikatan Ahli Ekonomi Islam), tetapi semua stakeholder yang harus bekerja sama dengan pemerintah (Depkeu, BI, Departemen terkait), ulama, parlemen (DPR/DPRD), perguruan tinggi, pengusaha (hartawan muslim), ormas Islam dan masyarakat Islam pada umumnya.

"Mereka harus mempercepat perkembangan ekonomi. Masalah sosialisasi dan edukasi masyarakat tentang ekonomi syariah juga saat ini masih minim. Ini harus terus-menerus dilakukan sosialisasinya, karena tingkat pemahaman dan pengetahuan masyarakat tentang ekonomi syariah masih sangat rendah," katanya.

\section{KESIMPULAN}

Pengertian pembangunan ekonomi dalam Islam, berdasarkan pemahaman terhadap syari'ah, bersumber dari al-qur'ân dan al-hadîs, dengan penekanan bahwa keberhasilan pembangunan harus disertai pengetahuan tentang konsep-konsep pembangunan klasik dan modern, serta pengalaman negara-negara yang telah berhasil dalam melakukan usaha pembangunan. Konsepsi ekonomi Islam mengacu pada syariah yang menjadi aturan agama kita. Sebab setiap perbuatan manusia termasuk kebijakan ekonomi dan pembangunan, serta aktivitas ekonomi masyarakat harus terikat hukum syara.

Perkembangan perbankan syariah pada dasarnya merupakan bagian penting yang tidak terpisahkan dari perkembangan ekonomi Islam. Salah satu alternatif yang sesuai untuk diterapkan di Indonesia dalam rangka memperbaiki keterpurukan ekonomi yang terjadi di Indonesia dewasa ini adalah dengan cara mengembangbiakkan Perbankan Syariah yang beroperasional secara syariah Islam secara lebih luas. Tentunya pengembangan Perbankan Syariah ini tidak dapat berhasil dengan baik apabila tidak ada dukungan dari semua pihak baik pemerintah, ulama, cendekiawan, pengusaha, pengelola Bank bahkan masyarakat sendiri serta adanya satu kesatuan pola pikir tentang Bank Syariah dari semua pihak tersebut di atas, sehingga dalam perjalanan/operasional Bank Syariah tidak lagi ditemukan adanya perbedaan pendapat yang kontroversial. Karena kontroversi yang merebak hanya akan membingungkan umat, yang berakibat kepada 
keraguan mereka untuk menyambut kehadiran "bayi ekonomi Islam" yang untuk masa sekarang ini muncul sebagai pionir dalam bentuk/matra Perbankan Syariah.

Kekurang berhasilan Perbankan Syariah di Indonesia dikhawatirkan akan semakin menjauhkan umat dari kepercayaan atas kemungkinan diterapkannya konsep ekonomi Islam didalam kehidupan nyata.

\section{DAFTAR PUSTAKA}

Hasibuan, Sayuti. 2009. Ekonomi Syariah Dan Perlunya Konsistensi Dalam Membangun Ekonomi Syariah. Surakarta: Univ. Muhammadiyah Surakarta (Disajikan pada Seminar Nasional Ekonomi Syariah: Menuju Perekonomian Indonesia Berbasis Syariah, UAI, 17 Juni 2009).

\section{Rama, Ali. Analisis Kontribusi Perbankan Syariah Terhadap Pertumbuhan Ekonomi Indonesia. Malaysia: International Islamic University Malaysia (IIUM).}

Undang-Undang Republik Indonesia Nomor 21 Tahun 2008 Tentang Perbankan Syariah （www.bi.go.id/id/tentangbi/uu-bi/Documents/UU_21_08

Syariah.pdf)

https://vhara.wordpress.com/perkembanganekonomi-islam-di-indonesia/ (diakses pada 25 Mei 2016) http://ekonomiprofetik.wordpress.com/2009/03 /24/perkembangan-ekonomi-syariahdiindonesia-dan-kontribusinya-bagipembangunan-nasional/ diakses pada 26 Mei 2016

http://sirizky.blogspot.co.id/2012/05/perekono mian-ummat-islam-pada-masa.html (Sumber: Drs. Ec. H. Tjuk K Sukiadi Komisaris Utama PT. BPR Syariah Baktimakmur Indah Sidoarjo)

http://www.pendidikanekonomi.com/2012/12/a nalisis-prospek-kontribusiekonomi.html

http://jurnal-ekonomi.org/konsepsi-ekonomiislam-untuk-pembangunan-ekonomi/

http://gideck.blogspot.co.id/2012/02/ekonomipembangunan-islam.html

http://bukhoridpr.blogspot.co.id/2013/12/islamuntuk-seluruh-aspek-kehidupan.html 